\title{
The FRP and TRC strengthening of the masonry structures
}

\author{
Arkady Granovsky, Oleg Simakov* and Bulat Dzhamuev \\ Moscow State University of Civil Engineering, Yaroslavskoye Shosse, 26, Moscow, 129337, Russia
}

\begin{abstract}
The use of external reinforcement based on carbon fibers is technically and economically justified to strengthen concrete structures, which is confirmed by years of experience. The use of this method of reinforcement for masonry structures has significantly less history and, accordingly, experience. However, experimental and site specific efficacy of the use of external reinforcement in the amplification of the pillars of masonry by the device holder has been proven. The experiments of strengthening of a brickwork carried out earlier, as well as the developed theory of calculation, concern application of a full-bodied brick. Given the volume of construction of large-format ceramic stone, the task of strengthening structures from it becomes more urgent every year. In order to solve this problem, the present experimental studies were carried out experimental studies of the clip effect on the fragments of brickwork with the strengthening of the external reinforcement system based on carbon fibers. In addition to studies of the influence of the size of bricks and the presence of voids, there was a study of the possibility of strengthening the samples with a cross-section size ratio of more than 2. In this case, carbon through anchors were mounted in the Central part of the samples. The test results obtained characters of destruction of specimens, the ultimate loadbearing capacity, made the appropriate conclusions.
\end{abstract}

\section{Purpose of research}

- to estimate the effect of the method of strengthening of centrally and extra-centrally compressed stone piers and pillars with the aspect ratio a / b $\leq 2$ and a / b $>2$ using carbon tape on their bearing capacity;

- too, but using carbon fiber-based mesh to reinforce masonry.

Prototypes of fragments of walls and columns were made of ceramic bricks and stones:

- ceramic hollow brick (voidness 41.1\%) PORONORM 1 (1 NF) - Fig. 1 a;

- ceramic large-format stone (voidness 54\%) POROMAX 280 (12.3 NF) - Fig. 1 b;

- full-bodied ceramic brick-rice. $1.1 \mathrm{c}$

\footnotetext{
* Corresponding author: simakovoa@mgsu.ru
} 
a)

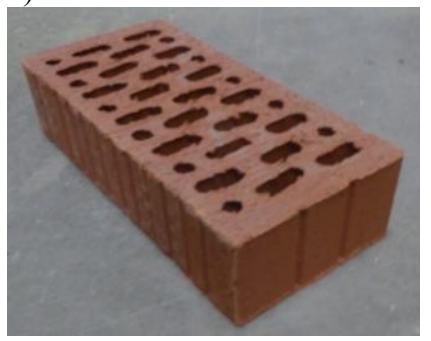

c)

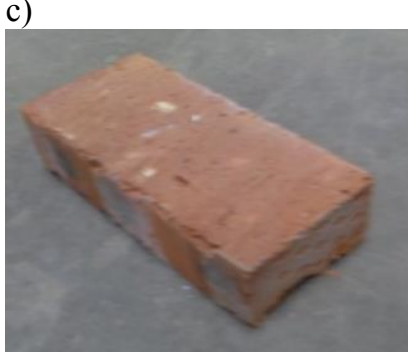

b)

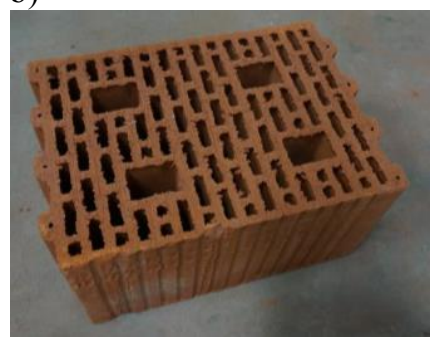

Fig. 1. Types of source materials of masonry specimens.

\section{Experimental study}

\subsection{Experimental samples}

Reference samples-brick pillars without carbon reinforcement. The test results of this series of samples was a "benchmark" that allows to evaluate the efficiency of the proposed in this work, the method of strengthening using of materials based on carbon fibers with respect to the traditional, unstrengthening, designs of brick pillars. From each batch of bricks delivered from the brick factory, reference (non-reinforced) samples were made in parallel with experimental (reinforced) samples of brick pillars of the I $\div$ VI series. This made it possible to more accurately take into account the effect of strengthening when using each batch of bricks and mortar for masonry from one batch in the manufacture of both reference and reinforced samples.

I-I series of samples-brick pillars reinforced with strips of carbon tape glued to the masonry through one on the second row in height of the column (Fig.2 (a).

II-I series of samples-brick pillars, reinforced with strips of carbon tape, glued to the masonry through two rows at the third height of the column (Fig.2 b).

III-series samples of the brick pillars reinforced with strips of carbon tape pasted on the walls in four rows on the fifth height of the pillar (Fig.2 b).

The fourth series of samples are brick pillars reinforced by wrapping the samples with carbon tape (Fig.2 g).

VI series of samples-brick pillars with a length of $38 \times 77 \mathrm{~cm}$ cross-sectional sides, reinforced with strips of carbon tape through two rows to the third. This series of experimental samples analyzed the effect of strengthening the brick pillars with the ratio of the sample sides 1: 2 and the presence of intermediate transverse rods (Fig.2 e).

VI-series of samples-brick pillars with an aspect ratio of $38 \times 51 \mathrm{~cm}$ at a height of 114 $\mathrm{cm}$ sample Strengthening of samples was carried out with the help of carbon tapes $230 \mathrm{~mm}$ wide, ie, when strengthening the carbon material overlapped three rows of masonry, and the distance between the tapes was $\sim 15 \mathrm{~cm}$ (two rows of masonry). 
a)

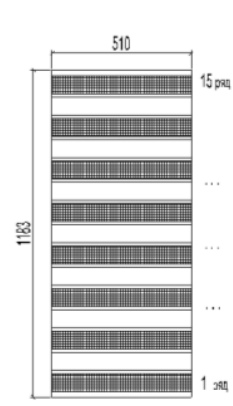

b)

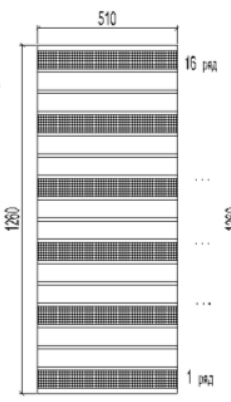

c)

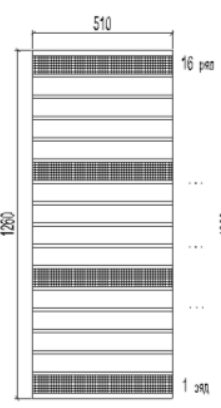

d)

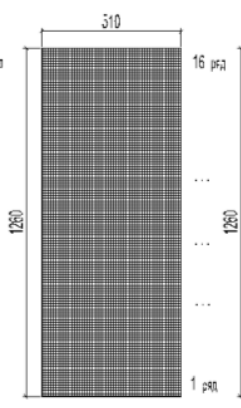

e)

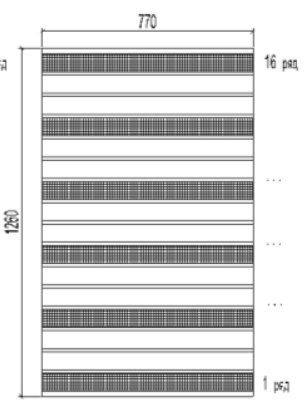

Fig. 2. General view of the experimental samples.

\subsection{Experimental samples}

The test circuit is shown in Fig. 3.
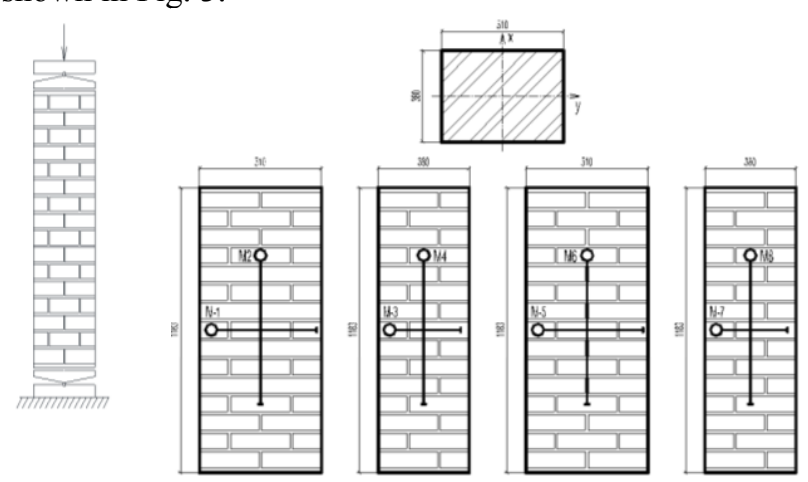

Fig. 3. General view of the test circuit.

The adopted scheme of fastening the column in the upper and lower levels corresponded to the hinge connection of the structure with the supports of the press. For rice. 3 schemes of arrangement of measuring devices for measurement of sizes of vertical and horizontal deformations of a laying at its compression are shown. Measurement of deformations was carried out using indicating gages with divisions of $0.01 \mathrm{~mm}$. the Tests were carried out according to the method adopted for reinforced concrete structures according to GOST 8829-94.
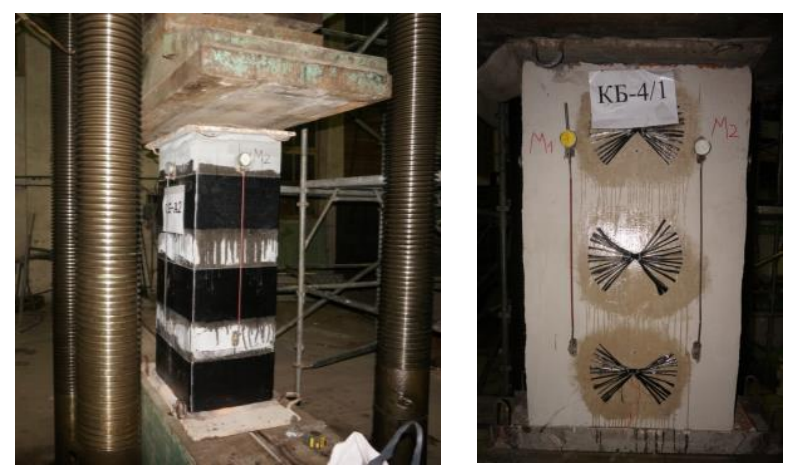

Fig. 4. Sample photos. 


\subsection{Test result}

Table 1 presents data on the results of the tests of masonry prototypes of solid and hollow ceramic bricks.

Table 1. The results of the tests.

\begin{tabular}{|l|c|c|c|}
\hline \multicolumn{1}{|c|}{ Sample } & $\begin{array}{c}\text { The cross-sectional dimensions of, } \\
\text { sm }\end{array}$ & Relative strength of masonry (\%) \\
\hline Reference sample & $38 \times 51$ & \multicolumn{2}{|c|}{100} \\
\hline I series & $38 \times 51$ & 160 & \multirow{2}{*}{166} \\
\hline II series & $38 \times 51$ & 172 & 133 \\
\hline V series & $38 \times 77$ & & 260 \\
\hline III series & $38 \times 51$ & \multicolumn{2}{|c|}{163} \\
\hline IV series & $38 \times 51$ & 260 \\
\hline VI series & $38 \times 51$ & \\
\hline
\end{tabular}

In accordance with the program of work under the contract were tested experimental stone piers made of large-format ceramic stone voidness $54 \%$, reinforced with nets and ribbons of carbon fiber. For carrying out tests prototypes of piers with the following sizes were made:

- samples of I $\div$ III series with cross-section sizes $280 \times 800 \mathrm{~mm}$;

- samples of IV $\div \mathrm{V}$ series with cross-section sizes $280 \times 600 \mathrm{~mm}$;

The choice of the specified sizes of piers allowed to estimate durability of a laying at a ratio of the parties of piers equal to two thicknesses (samples IV $\div \mathrm{V}$ series) and more, than two thicknesses (I $\div$ III series). Schemes of strengthening of samples with use of a carbon grid and a tape are shown in Fig. 2.

The size of the meshes (width) was chosen from the condition of overlap of one of the joints of masonry and sizes directly stone. At a height of $215 \mathrm{~mm}$, the width of the carbon mesh and tape was $300 \mathrm{~mm}$.

Table 1 shows the results of the tests and their treatment for $\mathrm{I} \div \mathrm{V}$ series samples mounted from large-format ceramic stone on cement mortar.

Analysis of the results of experimental data processing allows us to note the following.

1. The bearing capacity of the experimental samples of the I-series piers mounted from large-format ceramic stones and reinforced with carbon strips $300 \mathrm{~mm}$ wide (at a distance between the tapes $220 \mathrm{~mm}$ ) increased by $26 \%$ compared to the non-violent reference samples.

With a similar scheme of strengthening the piers of large-format stone using carbon fiber mesh (II series), the increase in the strength of the masonry was $16 \%$ compared with non-bitten samples. At the same time, in the samples of the I series (strengthening by carbon tapes), the destruction of the masonry occurred between the elements of strengthening without violating the integrity of the tapes themselves. In samples II series (increased carbon mesh in single layer) laying destruction began with the breaking of the mesh in corner areas with the subsequent destruction of the stones.

Given the lower density of the carbon mesh compared to carbon tapes, it is recommended to produce two layers of mesh reinforcement.

2. The carrying capacity of the experimental samples of the III series mounted from ceramic large-format stones and reinforced with carbon tapes by their complete wrapping 
increased by an average of $31 \%$ compared with non-bitten samples. At the same time, the compressive stresses in the masonry at the time of destruction were close to the branded strength of the stone during compression.

3. Bearing capacity of experimental samples of piers IV series with sizes in terms 280х600мм made from large stone and reinforced mesh-based carbon fiber according to the scheme similar to the samples of the II series (with sizes in terms $280 \mathrm{x} 800 \mathrm{Mm}$ ) increased by $29 \%$ compared to pusilanime samples. In this case, the nature of the destruction of the samples of the IV series is similar to the scheme of destruction of the samples of the II series.

4. Bearing capacity of experimental samples of piers $\mathrm{V}$ series with dimensions in terms of $280 \mathrm{~h} 660 \mathrm{~mm}$, made of large-format stone and reinforced with carbon tapes according to the scheme shown in Fig.2, increased by 55\% compared to non-violent samples. At the same time, the compressive stresses in the masonry at the time of destruction almost coincided with the compressive strength of the stone (stone grade). At the stone grade M100 (100 kgf/cm2), the stress in the masonry at the time of its destruction was 97 $\mathrm{kgf} / \mathrm{cm} 2$. .

The results of the tests of the $\mathrm{V}$-series samples allow us to conclude that the adopted model of strengthening with carbon tapes and grids allowed the most complete use of the strength of the stone.

\subsection{Conclusion}

1. When using carbon tapes to strengthen brick pillars by the method of external reinforcement, the following is established:

device, tire carbon strips (or meshes) width 65-70mm allows, depending on the adopted scheme of gain (pitch ribbons along the height of the sample) to increase the strength of masonry in $1.33 \div 2.6$ times compared to reference walls (see table 1 ).

2. If you are using strips (or grids) based on carbon fibers with a width of $22.5 \div 24 \mathrm{~cm}$ (three rows of masonry height of structure) with a pitch (distance between strips) $15 \div 16 \mathrm{~cm}$ the strength of masonry increases 1.63 times compared to reference.

3. If you are using strips (or grids) based on carbon fibers with a width of $300 \mathrm{~mm}$ with the distance between the canvases $220 \mathrm{~mm}$ allows you to increase the strength of masonry in $1.16 \div 1.55$ times compared with the brickwork reference (see table.1).

4. From the results of the experiment it follows that the destruction of masonry, reinforced with carbon fiber meshes, is due to the rupture of the mesh in the corner zones of the masonry. At the same time, when used to strengthen carbon tapes destruction of samples occurs on the "body" of the masonry between the elements of strengthening .

In this regard, it is recommended that the number of layers of strengthening of masonry by means of grids of carbon fiber to increase by one layer compared with the masonry, the reinforced carbon ribbons. For stone piers made of ceramic brick or stone to reduce the cost of reinforcement elements (carbon grids), the reinforcement scheme shown in figure is recommended.5. 


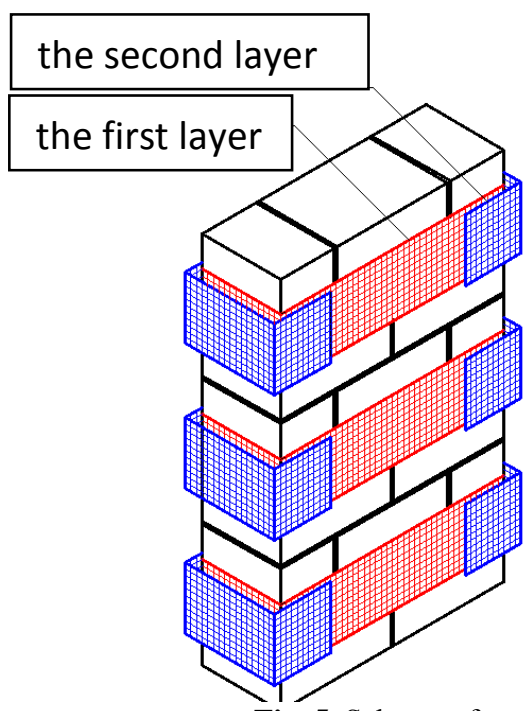

Fig. 5. Scheme of strengthening of a laying by a carbon grid.

5. The scheme of strengthening of masonry with ceramic bricks and stones when the width of the strips (grids) - 300mm is adopted in the experiment on the basis of existing recommendations for strengthening reinforced concrete columns.

6. to ensure the required level of fire resistance of stone structures reinforced with composite materials, it is recommended to use fire-retardant coatings in case of strengthening with carbon tapes using epoxy adhesives. In the case of carbon mesh reinforcement, the use of flame retardants is not required.

\section{References}

1. Vinogradova N. A., Teplova Zh. S. Constraints use of composite reinforcement. Molodoy uchenyy, 2016, 17, pp. 31-35. (In Russian).

2. Davidyuk A. N., Stepanova V. F., Buchkin A. V. Road composites. Prospects of application of composite materials in the construction industry. Stroitelnaya gazeta, no. 35 (10410). 2 sentyabrya 2016 g. (In Russian).

3. Stepanova V. F., et al. Armatura kompozitnaya polimernaya [Fittings composite polymer]. Moscow, 2013. 195 p. (In Russian).

4. Tonkikh G. P., Kabantsev O. V., Granovskiy A. V., Simakov O. A. Experimental study of seismic strengthening of masonry system of external reinforcement based on carbon fiber. Vestnik TGASU, 2014, 6, pp. 57-69. (In Russian).

5. Gasiev A. A., Granovskiy A. V. To the question of evaluation of load-bearing capacity of brick piers reinforced with sheets of carbon-fiber fabric under the action of shearing loads. Promyshlennoe i grazhdanskoe stroitel'stvo, 2015, 6, pp. 36-42. (In Russian).

6. Granovskiy A. V., Dzhamuev B. K. The use of carbonfber fabrics for strengthening the walls of cell concrete blocks in buildings constructed in earthquake-prone regions. Promyshlennoe i grazhdanskoe stroitel'stvo, 2012, 4, pp. 73-76. (In Russian).

7. Granovskiy A. V., Dzhamuev B. K., Dottuev A. I. The use of composite mesh on the basis of basalt fiber for reinforcement of masonry. Promyshlennoe i grazhdanskoe stroitel'stvo, 2016, 5, pp. 31-35. (In Russian). 